\title{
First record of Goldlined seabream Rhabdosargus sarba (Forsskål 1775), Sparidae, in the Mediterranean Sea (Syrian waters)
}

\author{
Nader Hamwi ${ }^{1 *}$ (D) and Nour Ali-Basha ${ }^{2}$
}

\begin{abstract}
This paper presents the first record of Rhabdosargus sarba (Forsskål 1775) in the Mediterranean Sea and the Syrian marine waters. One specimen (163 mm TL, $66.45 \mathrm{~g}$ TW) was caught by trammel nets at a depth range between 50 and $60 \mathrm{~m}$, from Lattakia coast, on 31 January 2021. This record represents the first sighting of this immigrant species that entered the Mediterranean Sea to Syrian waters from the Red Sea. the key to the species of Rhabdosargus is provided.
\end{abstract}

Keywords: Rhabdosargus sarba, Goldlined seabream, Sparidae, Syrian waters

\section{Introduction}

The sparid genus Rhabdosargus (Fowler 1933) are all characterized by large molariform teeth on both jaws and a stumpnose head (Smith and Smith 1986; Carpenter and Niem 2001), in addition to a silvery-black body with golden longitudinal lines, and often yellow pelvic and anal fins. The body often has black vertical bands (Smith 1979). The genus Rhabdosargus includes six species have been recognized as valid species (Tanaka and Iwatsuki 2013): Rhabdosargus sarba (Forsskål 1775), Rhabdosargus haffara (Forsskål 1775), Rhabdosargus globiceps (Valenciennes in Cuvier and Valenciennes 1830), Rhabdosargus holubi (Steindachner 1881), Rhabdosargus thorpei (Smith 1979), and Rhabdosargus niger (Tanaka and Iwatsuki 2013). The genus Rhabdosargus is represented in the Syrian marine waters by one species: Rhabdosargus haffara (Saad 2005).

The Goldlined Seabream Rhabdosargus sarba (Forsskål 1775), is a sparid fish commonly found in subtropical inshore waters of the Indo-West Pacific including the Red Sea, East

\footnotetext{
* Correspondence: nader836@gmail.com

${ }^{1}$ Ichthyology Laboratory, Faculty of Veterinary medicine, Hama University, Hama, Syria

Full list of author information is available at the end of the article
}

Africa, South Africa, Mozambique Channel, Seychelles, Madagascar and Mascarenes, east to Philippines, north to southern Japan, south to northern Australia. This species can presumably be found in a wider range in Oman, Iran, India and Bangladesh and has been reported from Pakistan (Bianchi 1985; Siddiqui et al. 2014).

$R$. sarba inhabits coastal waters, usually entering estuaries. It feeds on benthic invertebrates, mainly mollusks and aquatic macrophytes. Sexes are separate but some individuals are protandrous. (Froese and Pauly 2020).

This species has not been reported before in the Mediterranean Sea (Froese and Pauly 2020), so we present here the first occurrence of $R$. sarba from Syrian waters, and also from the Mediterranean Sea.

\section{Materials and methods}

One specimen of $R$. sarba was caught on 31 January 2021, with a surface seawater temperature of 19.7 C, it was caught during artisanal fishing operation, using trammel nets at a depth range between 50 and $60 \mathrm{~m}$, from south of Lattakia city (Fig. 1).

The specimen was measured to the nearest $(\mathrm{mm})$, weighted to the nearest (g) and morphometric

(c) The Author(s). 2021 Open Access This article is licensed under a Creative Commons Attribution 4.0 International License, which permits use, sharing, adaptation, distribution and reproduction in any medium or format, as long as you give appropriate credit to the original author(s) and the source, provide a link to the Creative Commons licence, and indicate if changes were made. The images or other third party material in this article are included in the article's Creative Commons licence, unless indicated otherwise in a credit line to the material. If material is not included in the article's Creative Commons licence and your intended use is not permitted by statutory regulation or exceeds the permitted use, you will need to obtain permission directly from the copyright holder. To view a copy of this licence, visit http://creativecommons.org/licenses/by/4.0/. 


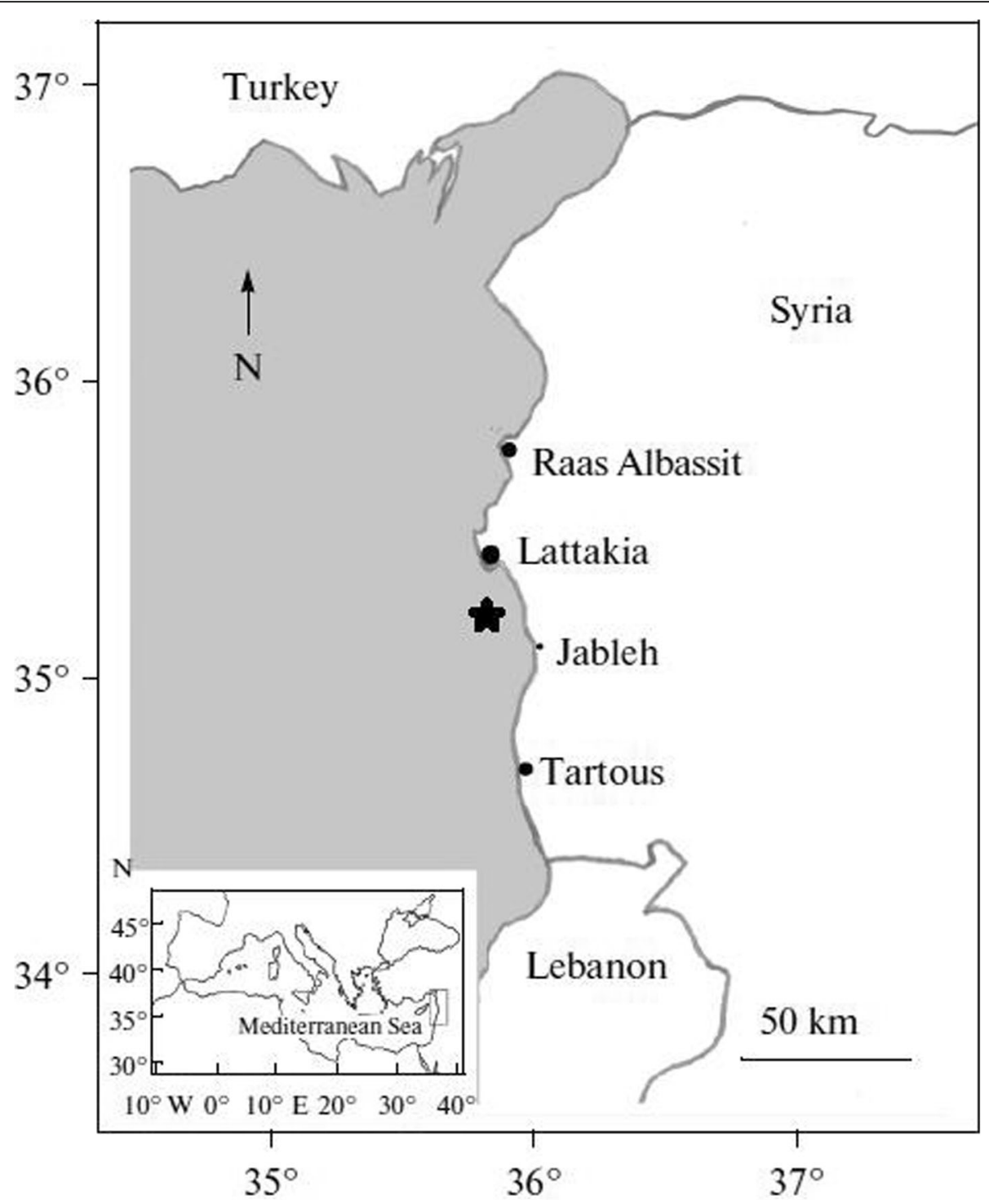

Fig. 1 Map of the Levantine Basin showing the location of fishing of Rhabdosargus sarba on Syrian coast

measurements with percentages of standard length (SL). The specimen was preserved in 10\% buffered formalin and deposited in the Ichthyological collection of the laboratory (Fig. 2).

\section{Results}

R. sarba specimen has a total length (TL) $163 \mathrm{~mm}$, with total weight (TW) $66.45 \mathrm{~g}$. Morphometric and Meristic data of the specimen is summarized in (Table 1). The specimen of this species presents the following characteristics: Body deep (depth about 2 times in standard length), compressed. Head large; upper profile steep, most strongly arched from snout to origin of dorsal fin; eye moderate to small in large specimens; mouth almost horizontal, low. At front of jaws, 4 to 6 upper, and 6 to 8 lower, enlarged, compressed teeth, becoming subconical in large adults, followed by 4 or 5 rows of molar teeth in posterior part of upper jaw and, 2 to 4 rows in lower jaw, the last molar in each jaw largest (Fig. 3, a, b). Gill rakers short, few, 7 to 9 on lower limb of first gill arch. Dorsal fin single, with XI or XII slender spines and 13 (rarely 12) to 15 soft rays, third and fourth spines longest. Anal fin with III spines and 11 soft rays, second and third spines subequal; pectoral fins long. Pelvic fins not reaching anus. Caudal fin forked. Scales cycloid (smooth), more than 50 in lateral line; $5 \frac{1}{2}$ or $6 \frac{1 / 2}{2}$ scale rows between lateral line and fourth dorsal-fin spine; preopercle flange naked; dorsal and anal fins with a low scaly sheath; a long axillary pelvic process. Color of fresh specimens: Head and body silvery-yellowish black; body with yellow or golden longitudinal lines; eye yellow with dark area; operculum silvery; yellow or yellowish 


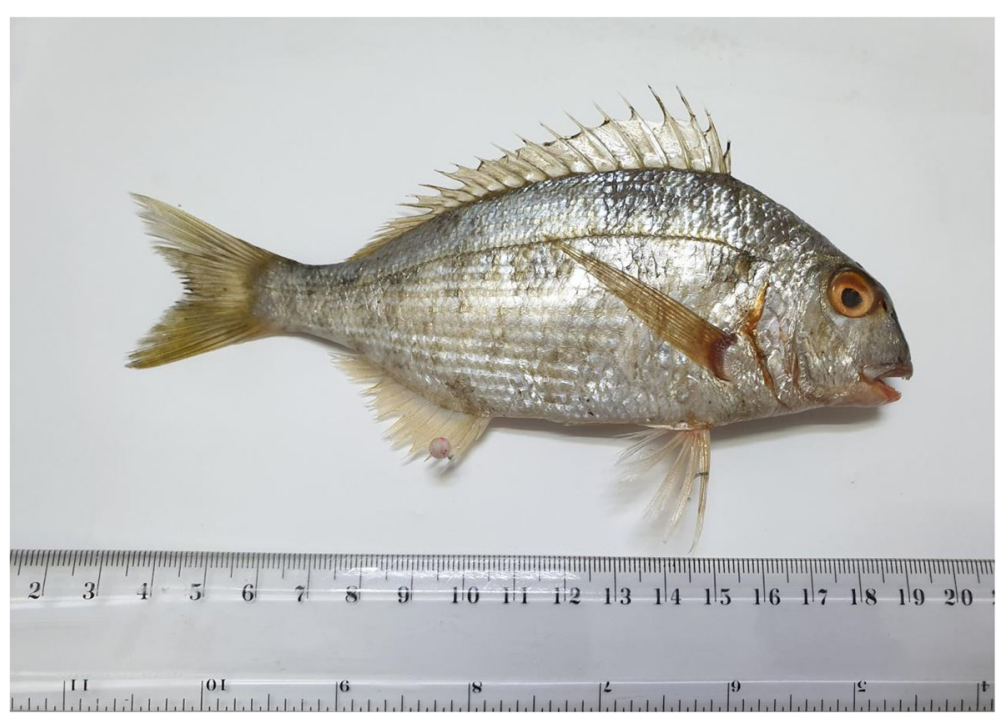

Fig. 2 Rhabdosargus sarba with $163 \mathrm{~mm} \mathrm{TL}$, caught off south of Lattakia city

Table 1 Morphometric measurements in $\mathrm{mm}$ and as a percentage of standard length (\%SL), counts and weight in grams recorded in the specimen of Rhabdosargus sarba caught off the Syrian coast

\begin{tabular}{lll}
\hline Morphometric measurements & $\mathbf{m m}$ & SL\% \\
\hline Total length (TL) & 163 & $124.4 \%$ \\
Fork length (FL) & 146 & $111.5 \%$ \\
Standard length (SL) & 131 & $100 \%$ \\
Body depth (BD) & 60 & $45.80 \%$ \\
Head length & 36 & $27.5 \%$ \\
Eye diameter & 10 & $7.63 \%$ \\
Pre-orbital length & 10 & $7.63 \%$ \\
Post-orbital length & 14 & $10.7 \%$ \\
Pre-dorsal length & 42 & $32.06 \%$ \\
Dorsal fin base length & 69 & $52.7 \%$ \\
Pectoral length & 45 & $34.4 \%$ \\
Pre-anal length & 82 & $62.6 \%$ \\
Anal fin base length & 25 & $19.08 \%$ \\
Counts & & \\
Dorsal fin rays & $\mathrm{XI}+13$ & \\
Anal fin rays & III + 11 \\
Pectoral fin rays & 14 & \\
Pored lateral- line scales & 60 & \\
Scale rows above / below lateral line & $61 / 2-141 / 2$ & \\
Gill rakers & $5+8=13$ & \\
Standard length/ body depth & 2.18 & \\
Total weight (TW) g & 66.45 & \\
\hline
\end{tabular}

coloration of pectoral, pelvic and anal fins; edges of dorsal and caudal fins are grayish, sometimes golden shade on caudal fin just after the caudal peduncle; pectoral-fins hyaline with light yellowish shade; chin and belly silverywhite; Body and head Silvery with yellowish or gold sheen (Fig. 4).

\section{Discussion}

All measurements, counts, and colour patterns determined the morphological analyses in previous other records of this species in Western Indian Ocean (Bauchot and Smith 1984), South Africa (Smith and Smith 1986), Western central Pacific (Carpenter and Niem 2001) and Australia (Dianne 2021).

$R$. sarba distinguish from $R$. haffara that has been recorded previous in our waters, they can be confused in terms of general appearance, but $R$. sarba differs from $R$. haffara in having 12-14 dorsal-fin soft rays and 10-11 anal-fin soft rays vs. 12-13 dorsal-fin soft rays and 10 anal-fin soft rays in $R$. haffara (Table 2) (Smith and Smith 1986; Heemstra and Heemstra 2004; Tanaka and Iwatsuki 2013). $R$. sarba discernible from $R$. haffara in having higher counts of pored lateral-line scales and scales rows above/ below lateral line (56-64 and $61 / 2-8^{1 / 2}$ / $12^{1 / 2}-14^{1 / 2}$ in $R$. sarba vs. $57-59$ and $5 \frac{1}{2}-6^{1 / 2} / 12^{1 / 2-13^{1 / 2}}$ in $R$. haffara, respectively) (Table 2). In addition, $R$. sarba has a silvery body and head with yellowish or gold sheen, while $R$. haffara possesses a silvery body and head (Table 2).

$R$. sarba has not already been mentioned in the Mediterranean Sea, so our research represents the first record in the Mediterranean Sea and Syrian waters. It is probably an immigrant species from the Red Sea into Levantine Basin. The observed specimen was found mixing 

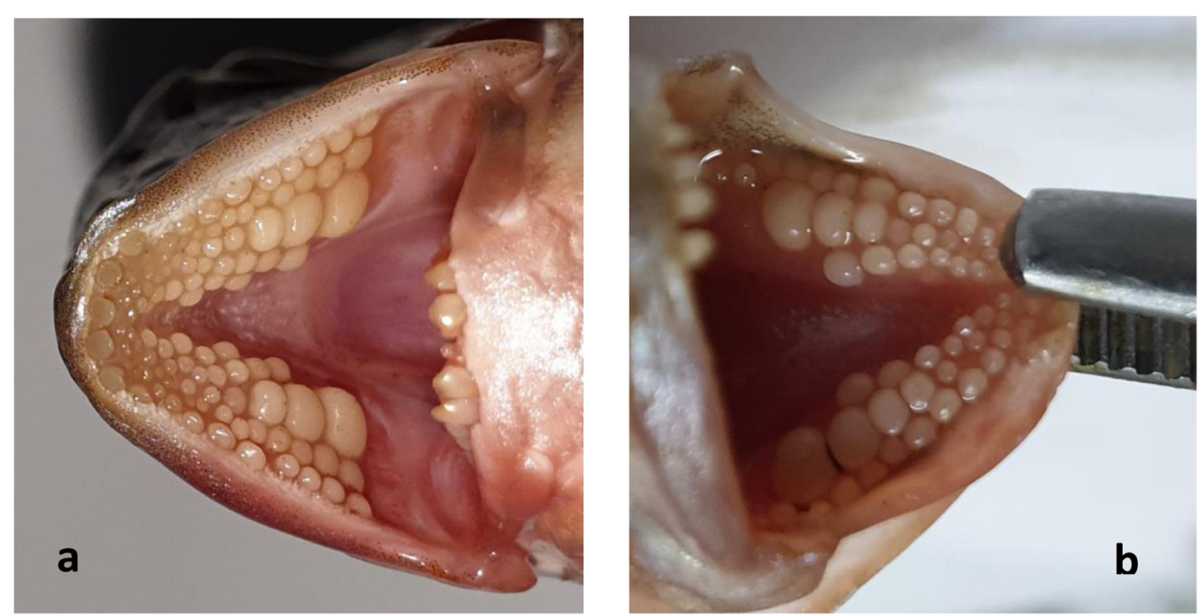

Fig. 3 a Upper jaw b Lower jaw

within populations of one other Sparid species Diplodus sargus (Linnaeus 1758) and two Siganid species Siganus luridus (Rüppell 1829) and Siganus rivulatus (Forsskål and Niebuhr 1775).

\section{Conclusion}

A specimen of $R$. sarba was captured from Syrian waters, mixed with populations of Diplodus sargus, Siganus rivulatus and Siganus luridus. The record in the Syrian waters represents the first report of this species in the Mediterranean Sea. We suppose that is an immigrant species from the Red Sea. The single specimen does not necessarily indicate a settled population at this area.

Key to the species of Rhabdosargus from the IndoWest Pacific: (Tanaka and Iwatsuki 2013)

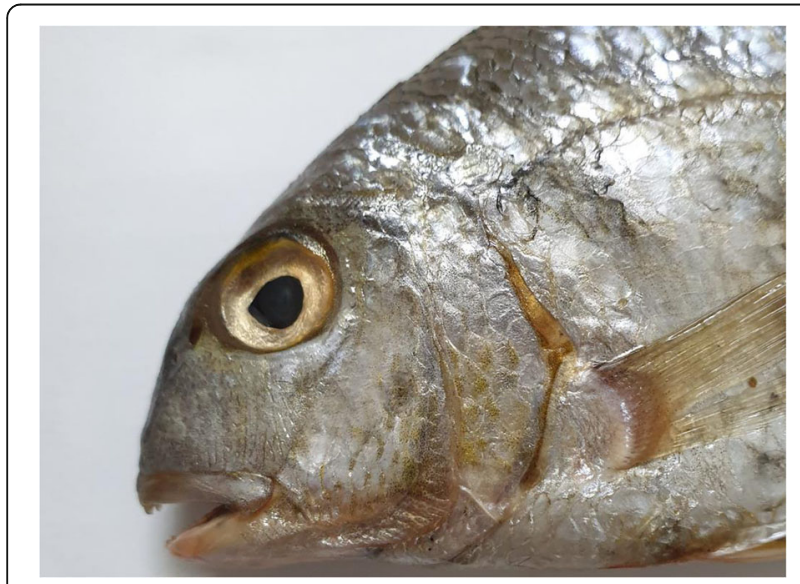

Fig. 4 Head coloration of Rhabdosargus sarba 1a. Body with six or seven narrow vertical dark crossbars; dorsal-fin soft rays 11 (rarely 12).

R. globiceps

1b. Body lacking vertical cross-bars or at most very faint on body; dorsal-fin soft rays $12-13$..........2 2a. Golden mid-lateral stripe along body; $2-8$ embedded scales on preopercular flange; black spot on upper end of pectoral-fin base R. holubi

Table 2 Selected characters of $R$. sarba and R. haffara

\begin{tabular}{|c|c|c|}
\hline characters & R. sarba & R. haffara \\
\hline Dorsal-fin rays & $\begin{array}{l}\mathrm{XI}, 12-14 \text { (usually } \\
13)\end{array}$ & $X I, 12-13$ \\
\hline Anal-fin rays & III, 10-11 (rarely 10) & III, 10 \\
\hline Pectoral-fin rays & 14-16 (usually, 15) & $15-16$ \\
\hline Pored lateral-line scales & $56-64$ & $57-59$ \\
\hline Scale rows above/below lateral-line & $61 / 2-81 / 2 / 12 \frac{1}{2}-141 \frac{1}{2}$ & $\begin{array}{l}51 / 2-61 / 2 / \\
121 / 2-13 \frac{1}{2}\end{array}$ \\
\hline $\begin{array}{l}\text { Scale rows between the fifth dorsal- } \\
\text { fin spine base and lateral line }\end{array}$ & $61 / 2-71 / 2$ & $51 / 2-61 / 2$ \\
\hline Gill rakers & $5-6+7-9=12-15$ & $\begin{array}{l}6-7+8- \\
9=14-16\end{array}$ \\
\hline Standard length/ body depth & $2.0-2.2$ & $2.4-2.6$ \\
\hline Scales on preopercular flange & Absent & Absent \\
\hline $\begin{array}{l}14 \text { or } 15 \text { golden longitudinal lines on } \\
\text { body }\end{array}$ & Present & Present \\
\hline Dorsal head profile & Steep & Convex \\
\hline $\begin{array}{l}\text { Coloration of ventral area from breast } \\
\text { to above end of anal fin }\end{array}$ & Silvery-white & $\begin{array}{l}\text { Silvery- } \\
\text { white }\end{array}$ \\
\hline Body and head in color & $\begin{array}{l}\text { Silvery with } \\
\text { yellowish or gold } \\
\text { sheen }\end{array}$ & Silvery \\
\hline
\end{tabular}


2b. No golden mid-lateral stripe along body; preopercular flange entirely naked; no distinct black spot on upper end of pectoral-fin base .3

3a. Body slender, SL/body depth more than 2.4

$$
\text { R. haffara }
$$

3b. Body deeper, SL/body depth less than 2.3 .......... 4

4a. Lower gill rakers 10-12; anal-fin soft rays 11-12; ventral area from breast to above end of anal fin yellow R. thorpei

4b. Lower gill rakers 7-9; anal-fin soft rays 10-11; ventral area from breast to above end of anal fin silverywhite or light dusky 5

5 a. Scale rows between the fifth dorsal-fin spine base and lateral line $5 \frac{1}{2}$; pelvic and anal fins dusky gray.

\section{R. niger}

5b. Scale rows between the fifth dorsal-fin spine base and lateral line $6 \frac{1}{2}-7 \frac{1}{2}$; pelvic and anal fins more or less yellow or brownish-yellow R. sarba

\section{Acknowledgements}

We express our thanks to Mr. Khaled Tayara for bringing the specimen of $R$. sarba to our attention.

\section{Authors' contributions}

NA-B and HN examined specimen and drafted the manuscript. Both authors gave the final approval for publication.

\section{Funding}

Not applicable.

\section{Availability of data and materials}

The specimen is available at Ichthyology Laboratory- Hama university- HamaSyria.

\section{Declarations}

\section{Ethics approval and consent to participate}

No ethical approval or consent to participate was required.

\section{Consent for publication}

Not applicable.

\section{Competing interests}

The authors declare that they have no competing interests.

\section{Author details}

${ }^{1}$ Ichthyology Laboratory, Faculty of Veterinary medicine, Hama University, Hama, Syria. ${ }^{2}$ Marine Sciences Laboratory, Faculty of Agriculture, Tishreen

University, Lattakia, Syria.

Received: 26 February 2021 Accepted: 7 May 2021

Published online: 25 May 2021

\section{References}

Bauchot ML, Smith MM. Sparidae. In: Fischer W, Bianchi G, editors. FAO species identification sheets for fishery purposes. Western Indian Ocean (Fishing Area 51). volume 4. Rome: FAO; 1984.

Bianchi G. Field guide to the commercial marine and brackish-water species of Pakistan. Rome, PAK/77/033 and (FIRM): Fishery Resources and Environment Division, Fisheries Department, FAO; 1985. p. 200.

Carpenter KE, Niem VH. (eds) FAO species identification guide for fishery purposes. The living marine resources of the Western Central Pacific. Volume 5. Bony fishes part 3 (Menidae to Pomacentridae) Rome, FAO; 2001. p. 2791 3380.

Dianne J. Bray, Rhabdosargus sarba in Fishes of Australia, Accessed date 24 Feb 2021, http://136.154.202.208/home/species/679.
Fowler HW. Contributions to the biology of the Philippine Archipelago and adjacent regions. The fishes of the families Banjosidae, Lethrinidae, Sparidae, Girellidae, Kyphosidae, Oplegnathidae, Gerridae, Mullidae, Emmelichthyidae, Sciaenidae, Sillaginidae, Arripidae and Enoplosidae, collected by the United States Bureau of Fisheries steamer "Albatross," chiefly in Philippine seas and adjacent waters. US Nat Mus. 1933. Bull. 100, 12, vi + 465p.

Froese R, Pauly D. FishBase. World Wide Web electronic puplication. 2021. www. fishbase.org, version (02/ 2021).

Heemstra PC, Heemstra E. Coastal fishes of southern Africa. Grahamstown: The National Inquiry Service Centre (NISC) and The South African Institute for Aquatic Biodiversity (SAIAB); 2004.

Saad A. Check-list of bony fish collected from the coast of Syria. Turkish J Fish Aquatic Sci. 2005;5:99-106.

Siddiqui PJ, Amir SA, Masroor R. The sparid fishes of Pakistan, with new distribution records. Zootaxa. 2014;3857(1):071-100. https://doi.org/10.11646/ zootaxa.3857.1.3.

Smith JLB, Smith MM. Sparidae. In: Smith MM, Heemstra PC, editors. Smiths' sea fishes. Mac South Africa: Johannesburg; 1986. p. 580-94. https://doi.org/10.1 007/978-3-642-82858-4.

Smith MM. Rhabdosargus thorpei, a new sparid fish from South Africa, with a key to the species of Rhabdosargus. Copeia. 1979;1979(4):702-9. https://doi.org/1 $0.2307 / 1443880$

Tanaka F, Iwatsuki Y. Rhabdosargus niger (Perciformes: Sparidae), a new sparid species from Indonesia, with taxonomic status of the nominal species synonymized under Rhabdosargus sarba. Ichthyol Res. 2013;60(4):1-13. https://doi.org/10.1007/s10228-013-0360-0.

\section{Publisher's Note}

Springer Nature remains neutral with regard to jurisdictional claims in published maps and institutional affiliations.

\section{Ready to submit your research? Choose BMC and benefit from:}

- fast, convenient online submission

- thorough peer review by experienced researchers in your field

- rapid publication on acceptance

- support for research data, including large and complex data types

- gold Open Access which fosters wider collaboration and increased citations

- maximum visibility for your research: over $100 \mathrm{M}$ website views per year

At BMC, research is always in progress.

Learn more biomedcentral.com/submissions 